\title{
Analysis of Natural Education in America ---By The Glass Castle as an Example
}

\author{
Lei Guo ${ }^{1}$, Zhen $\mathrm{Ge}^{2 *}$ \\ ${ }^{1}$ The Associate Professor of North China Electric Power University in China \\ ${ }^{2}$ The Post-Graduate Student Majoring in English language and literature of North China Electric Power University in China
}

DOI: $\underline{10.36348 / \mathrm{sjhss} .2020 . \mathrm{v} 05 \mathrm{i} 05.002}$

| Received: 07.05.2020 | Accepted: 14.05.2020 | Published: 28.05.2020

*Corresponding author: Zhen Ge

\section{Abstract}

Along with the advancement of society and technology, education is becoming increasingly indispensable for daily life. Different educational model shapes different children's character that have a great influence in their life. Understanding is of importance to the transformation of educational ideas and different practices of education. Rousseau was a famous educator and he insisted that children should be educate in the nature without any control. This paper is stimulated by Rousseau's educational ideas in The Glass Castle and illustrates the enlightenment of China. Besides, it also shows the importance of natural education and family values in one's life.

Keywords: Education, educational ideas, Rousseau, natural education, The Glass Castle, family value.

\begin{abstract}
Copyright @ 2020: This is an open-access article distributed under the terms of the Creative Commons Attribution license which permits unrestricted use, distribution, and reproduction in any medium for non-commercial use (NonCommercial, or CC-BY-NC) provided the original author and source are credited.
\end{abstract}

\section{INTRODUCTION}

Education plays an indispensable role in promoting the development of human society and advancement of technology. Although every country attaches importance to education, they have different concepts of education due to various cultural background. Jean-Jacques was a major philosopher, writer, and composer in 18th Enlightenment. His political, social and educational thoughts had great influence on today's world. In his book Emile, it outlined the best way to educate human beings. He divided childhood into three stages: the 1st stage is from 1 to about 12, during this stage, the children are guided by their emotions and impulses. The 2 nd stage is from 12 to about 16 , and at the stage reason starts to develop; and the 3rd stage, from the age of 16 onwards. In his opinion, the childhood is a crucial stage. The importance of this stage is not just about how to impart knowledge, but to develop the character and moral sense of children, so that they could learn to "practice self-mastery and remain virtuous even in the unnatural and imperfect society in which he will have to live." (Jean-Jacques Rousseau Wikipedia) Besides, from Florence Kluckhohn's view of people's beliefs and behaviors, Rousseau's education also connects to relationship of humans to nature.
In academia, there are some researches on Rousseau's educational theory. His theory of education is based on his philosophical ideas. Lu illustrates Rousseau's two philosophical ideas on education [1]. Quan's paper argues that Rousseau's theory of education has a great impact on American elementary and secondary education because it stresses the physical and emotional development of the child, the importance of progressive education adapted to the individuals and the teacher must understand the child [2]. Song explains the main parts of the natural education thought and emphasizes the importance of Rousseau's theory [3]. Cui analyzes Rousseau's education thought to solve the current problems in the family education [4]. In a short, these researches' themes most connect with environmental education.

This paper will analyze the natural education in America by detailing the educational value in The Glass Castle. It not only gives a comprehensive interpretation for natural education, but also explains the enlightenment of natural education to China. The first part makes an introduction to Rousseau's educational concept and present research situation. The second part makes a detailed analysis the reflection of natural education thought in The Glass Castle. The third part shows China's traditional concept of education and indicates the inadequacy of it. The fourth part draws a conclusion that most Americans emphasize natural 
education due to their unique history and educational purposes and gives an enlightenment to China.

\section{Natural Education in America}

Most Americans emphasize natural education that develops independent living skills, creative ability, strong quality and so on. The Glass Castle reflects the natural education. The Glass Castle, a memoir, spent a total of 261 weeks on The New York Times Best Seller list. From the famous story Glass castle, it shows how important relationship of humans to nature is. The Glass Castle narrates the story of Jeannette Walls' family which is a strange and lovely family because of their spirit and marvelous experience. The father Rex is an alcoholic person and always makes empty promises, and the mother Rose Mary is a painter and artist. They have a land that is worth a million dollars but they give up the easy life instead to move around the country frequently. They choose this natural education to cultivate their children and forms their unique growth approach.

\section{Independent living skills of natural education}

Natural education is more and more important of children. Most Americans insist that natural education can improve children's independent abilities. Mountain goat, Jeannette, is the second daughter of Wall's family and author of the novel. Her father didn't have a job and her mother always was concentrated on her painting, so they had no money to buy food. When she was three years old, they were living in a trailer park in a southern Arizona town. Maybe you can't imagine a three years old girl can cook hot dogs standing on a chair in front of the stove. But it was true and happened in this novel. Her mother did not like cooking much in that she said that "When in the same amount of time, I can do a painting that will last forever? [5]." While Jeannette was hurt by fire, her mother was painting in the next room. The painting is her mother's life. When they went to the hospital, the nurses and doctors kept asking her questions: How did you get burned? Have your parents ever hurt you? Why do you have all these bruises and cuts? [5]. Jeannette answered them that her parents never hurt her, and she got cuts and bruises playing outside and the burns from cooking hot dog. In Jeannette's mind cooking the dog was easy and she explained the details of cooking dog. And this time, nurses were surprised and want to protect this girl from this life style. Doctors said she was lucky to be alive. When they second visited Jeannette, her brother Brian's head was wrapped in a dirty whited bandage with dried bloodstains due to he had fallen off the back of the couch and cracked his head open on the floor [5]. Besides her Dad Rex said Jeannette's burn need to breathe and clashed with doctor, and they had to leave this place. Furthermore, in the novel, Jeannette describes her second husband John how to thought of the scar. John thought the scar meant that she was stronger than whatever it was that had tried hurt to me. It is a brave spirit. He describes it "smooth" and "interesting". It shows the natural education thought of Walls family. Most America's parents believed that children shouldn't be burdened with a lot of rules and restrictions since they can have learned a lot from their mistakes. In short, it reveals that children should not grasp all the knowledge from books and classroom, but develop their independent living skills by themselves.

\section{Strong Quality of Natural Education}

Natural education can improve strong quality of children. The second plot is about that Rex taught Jeannette how to swim. Because her brother all knew how to swim, only she had never learned. She was afraid of drowning and describes the scene that "I worked up enough nerve to make my way around the entire length of the pool, clinging to the side [5]." Her father Rex helped her learn to swim together and encouraged her to be brave. He pushed her into the shallow to have her learn how to swim. He did it again and again so that finally she did it. Rex said to her that he loved her and never would have let her drown. But Rex told Jeannette that "If you don't want to sink, you better figure out how to swim [5]. It shows that every man can controls nature and the best way of education is not teach him by hand, but let children finished it by themselves even it is difficult. It shows that most American's natural education can improve child's strong quality and character when they facing difficulty in life.

\section{Inquiry learning of natural education}

Most Americans have an adventurous and creative spirit due to their unique history so they are adept in finding various ways of problems. Natural education can improve children's learning ability to face social challenges. The third plot is about how Wall's children acquire knowledge by natural education. They always acquired knowledge together. They read the dictionary and discussed with their father about the definitions of the words they didn't know. And if they didn't agree with what dictionary writers said, they would write letters to the publishers. It is a critical and creative spirit. They always read the book by creative thought rather than only read the book. Besides, their mother not only painted but also read many books, such as Charles Dickens, William Faulkner, Henry Miller, and Pearl. Her father Rex loved science and math books, biographies and history. He was smart and had a dream to build a glass castle for his daughter. So, they could receive much knowledge from their parents in daily life. Jeannette's brother read adventure and her sister Lori loved Freddy the Pig and all the Oz books. In short, in Wall's family every child was doing what they love rather than limited to their learning.

In addition, their father loved to talk about the stars with children, and taught them to identify the constellations and how to navigate by the north star. It was new for children. Rex sent a star to Jeannette as a 
Christmas gift, and named her favorite star as Venus. He explained that "Years from now, when all the junk they got broken and long forgotten, you'll still have your stars [5]." What an amazing gift! What a unique education way! These parents were poor and could not afford expensive presents, and they didn't want to send them fancy toys. But they used life experience to teach their children that inquiry learning can increase child's creative ability and the level of thinking.

\section{Summary}

From the above, natural education is a common educational way for Americans, and in The Glass Castle these parents don't limit their children's interest and encourage them to do what they like, which reflects the natural education. They insist this education style due to nature is the best teacher. Although their idealism and unique attitude to life has led four children to live in a land of hunger, poverty and inferiority, poverty is a kind of experience. In the last story, after five years since Dad Rex died, the first Walls family got together. Every child had own life and was happy. Jeannette got a second marriage with a writer John, Brian had become a decorated sergeant detective, Lori lived with their mother Mary, and Maureen was still living in California. It is influential of a childhood of fight and imagination rather than giving them a rich and comfortable life. They had many adventurous experiences that make children grow up naturally. Because children have much free time to study and play, they have a happy childhood. True natural education is the engine that can drive the dream of success. Just received a good education in school is not enough. Children should behave like children but not be "constrained or confined [6]," So, children should be given enough time and liberty to do what he likes. Maybe it is the core theme in Walls family. When they were young, their mother and father did not interfere with their growth and gave them time to travel and experience. They impart their children to textbook knowledge as well as their ability to survive. Because of natural education thought, every child has a wonderful life and achieve their dream. In short, American's natural education increases children's living skills, strong quality and learning ability. It develops wellrounded person for society and country and is beneficial for the improvement of national quality.

\section{The Enlightenment of Natural Education}

Firstly, China's traditional education value is about of Confucianism. For Confucius the major goal of education was not the transmission of knowledge or the learning of skills, it was the internalization of a set of ethical principles that governed human behavior in all conceivable situations [7]. So, in China, the morality of learning from childhood is a kind of natural education. People always pay attention to idea rather than ability. Secondly, Chinese emphasize the school education and family value. Thanks to Chinese paying attention to stable life, they have almost no such adventurous experience of the Wall's family. Although they acquired knowledge from the book, they could not apply their professional knowledge in practical life. In the eyes of teachers and parents, children are the tools of learning.

For example, many parents like "Tiger Mom Cat Dad" and the series finale attract tens of thousands of comments on Web. Tiger mom supervises the child carefully and she thinks it is her duty to let child make a good mark. Most Chinese parents think academic performance is everything. They violate the natural education thought for good grades to children. Children's activities are limited to desks and training classes. In that environment, children not only lack creativity and imagination, but also become introverted. As Rousseau said, the early years of a child's education should be focused on "developing the senses, not spent chained to a schoolroom desk [8]." However, most Chinese parents want to arrange their children's future and prepare for their career without child's permission. They think that when you study well, you will have a better future. This is a misunderstanding of education. Education is not the purpose of the training test machine, but to develop a sound body and mind and the modern citizens.

The real meaning of education is to teach children how to become intellectual and creative, or civilized. The enlightenment of America's education is that natural education is a best way for children that can increase their creativity and logical thinking. It is the foundation of national development in the long run, and natural education thought is a unique way to allow the child to grow up at all points of view. From the traditional culture of China, it is impossible to let children wander, but government and school can create more chances for children.

\section{CONCLUSION}

Rousseau's ideas have been influential and profound. His great philosophy of education emphasizes the physical and emotional development of the children and the teacher must understand the children's mind and attach great importance to the teaching methods. (Quan) It really can deepen our understanding of natural education thought. Natural education improves children's ability when they facing difficulties.

In the foregoing paragraphs, the significance of natural education has been explored and illustrated the enlightenment of China. By interpreting the natural education thought of The Glass Castle, we can get more understandings of western cultures. The process of wander is also a kind of education. We can't force children to learn and should make natural education. Just like children in The Glass Castle they acquire knowledge from life experiences and natural environment. Even burned by the flames Jeannette 
controlled fire. Natural education thought not only trains children's analytical thinking, but also provides the knowledge they can't get from books. Being full of passion and bravery to face any trouble in the future is the natural education thought's reflection. Their children always had been trained to find a way out in the face of adversity. They should take an upward outlook in life even in an adversity. The aim of education, just like A.N White said, is not to teach students many subjects. It is the acquisition of the art utilization of knowledge [9]. However, although China is also transitioning to natural education thought, most people's concept of education hasn't changed. American children concentrate on the process of learning while the Chinese children lay more emphasis on the results. China's children are passively receiving education. China's natural education way should be attached to importance. Being given the natural experience and book knowledge for children, they will adapt to the society more easily. All in all, implementing natural education thought is of great significance to social and economic development.

\section{REFERENCES}

1. 鲁娅妮. (2012). Rousseau's Philosophy Ideas on Education. 中国校外教育: 下旬, (6), 70-70.
2. 全 春艳. (2015). Rousseau's Philosophy of Education's Impact on American Elementary and Secondary Education [J]. 海外英语, (21):277-278.

3. 宋全成. (1999). 论卢梭的教育理论 (Doctoral dissertation). (2):63-67.

4. 崔帆. (2010). 卢梭自然教育思想对我国当前家 庭教育的启示 $[\mathrm{J}]$. 沈阳教育学院学报, 12(2):1215 .

5. Jeannette, W. (2005). The Glass Castle [M]. New York: Scribner.

6. Dent, N. J. H. (1992). A Rousseau Dictionary [M]. Oxford: Blackwell Publishers.

7. 吴艳华. (2016). Exploring Differences between American and Chinese Concept of Education. 海 外英语, (23), 183-184.

8. Perry, M. (1989). Chase Myrna, Jacob James R, Jacob Margaret C., Von Laue Theodore $H$. Western Civilization: ideas, politics \& society [M]. Boston: Houghton Mifflin company.

9. Young, D., Waitches, G., Birchmeier, C., Fasano, O., \& Wigler, M. (1986). Isolation and characterization of a new cellular oncogene encoding a protein with multiple potential transmembrane domains. Cell, 45(5), 711-719. 